Larsen, A., K. (2017). Samarbeid mellom

masterstudenter i yrkespedagogikk og deres kolleger på egen arbeidsplass. Scandinavian Journal of Vocations in development.

http://dx.doi.org/10.7577/sjvd.2011

\title{
Samarbeid mellom masterstudenter i yrkespedagogikk og deres kolleger på egen arbeidsplass
}

Forfatter:

Anne Karin Larsen

Høgskolen i Oslo og Akershus,

Fakultet for lærerutdanning og internasjonale studier, Institutt for yrkesfaglærerutdanning annekarin.larsen@hioa.no

Nøkkelord: yrkesfaglærerutdanning, masterstudenter, yrkespedagogikk, lærersamarbeid, læring, organisasjonslæring 


\section{Sammendrag}

Innledning: Det legges i økende grad vekt på samarbeid mellom skole og arbeidsliv i profesjonsutdanningene. Yrkesfaglærerstudenter blir oppfordret til å samarbeide med praksisfeltet under sine studier og lærerstedene fors $\varnothing$ ker å organisere undervisningen slik at dette blir mulig. Tanken om skolen som en lærende organisasjon gjennom $\varnothing k t$ kollegialt samarbeid og vilje for endring og utvikling er interessant. Men erfaringene fra tidligere studier viser at dette ikke er enkelt å oppnå, og vi vet lite om studentenes eget engasjement for å samarbeide. Studien er teoretisk forankret i kognitiv- og sosialkonstruktivistiske læringsteorier, hvor det fokuseres på deltakernes individuelle opplevelser av læringsprosessen og med særlig vekt på samspillet mellom aktørene i praksisfellesskapet. De fleste masterstudentene i studien er deltidsstudenter som til daglig arbeider som yrkesfaglærere i den videregående skolen. Hensikten med studien har vært å utvikle ny kunnskap om samarbeid mellom studentene, arbeidslivet og høgskolen, som et ledd i videre utvikling av masterstudiet i yrkespedagogikk, og å styrke profesjonslæringen.

Problemstilling: I hvilken grad er det sammenheng mellom studentenes initiativ til samarbeid og studentenes erfarte samarbeid med kolleger og arbeidsgiver? Har masteroppgaven ført til kompetanseutvikling på egen arbeidsplass eller kun for studentens egen utvikling?

Metode: Studien er basert på en kvantitativ spørreundersøkelse gjennomført ved Høgskolen i Oslo og Akershus, Institutt for yrkesfaglærerutdanningen, og utvalget består av 84 informanter som var deltidsstudenter ved masterstudiet i yrkespedagogikk i studieårene 2009 - 2012. Svarprosenten var 55\%. Data som ble innhentet ble analysert med bruk av regresjonsanalyse og reliabilitetsanalyse. Hensikten med spørreunders $\varnothing$ kelsen var å kartlegge i hvilken grad studentene generelt sett tok eget initiativ til å samarbeide med kolleger, og om det kan sies å være en sammenheng mellom grad av initiativ og erfart samarbeid. Dataene som fremkommer gjennom spørsmålene, er basert på studentenes egne refleksjoner og opplevelser av samarbeidsprosessen med kolleger og arbeidsgivere.

Resultatene viser en statistisk sammenheng mellom studentenes eget initiativ og opplevelsen av samarbeid med kollega eller arbeidsgiver, det vil si at en kollega eller leder har deltatt i forskningsarbeidet eksempelvis med innhenting av data, stilt sin undervisning til disposisjon for forskningen eller deltatt i analyse av resultater, refleksjon og diskusjon. Testene viser at dette kun skjer i en svært liten grad. Det er andre faktorer som spiller inn og disse er ikke tatt inn som variabler i unders $\varnothing$ kelsen. Selv om masterstudentene tar initiativ til å samarbeide med ledelse og kolleger, erfarer de i liten grad samarbeid med disse på egen arbeidsplass. Videre viser resultatene at kunnskap som oppnås hos den enkelte masterstudent, formidles sjelden til andre ansatte ved arbeidsplassen eller praksisfellesskapet.

Konklusjon:

Studien kan konkludere med at det er en sammenheng mellom studentenes initiativ til samarbeid og studentenes erfarte samarbeid med kolleger og arbeidsgiver. Det kan likevel ikke tas for gitt at kolleger og arbeidsgivere skal bli interessert selv om studentene tar initiativ til å samarbeide. Funnene aktualiserer videre forskning på andre aktuelle samarbeidsformer, hvor masterstudentene i yrkespedagogikk finner samarbeidspartnere eksternt og ikke internt på egen arbeidsplass. 


\section{Abstract}

Introduction: There is increasing emphasis on cooperation between schools and working life in professional education. Vocational teacher students are being encouraged to cooperate with the practical fields during their studies, and colleges try to organize their teaching in a way which makes that possible. The idea of a school as a learning organization by way of increased collegial cooperation and willingness for change and development is interesting. But experiences from previous studies show that it is not easy to achieve, and that we know little about the students' commitment in cooperating.

This study is theoretically embedded in cognitive and social constructivist learning theories, which focus on the participants' individual experiences of the learning process and with a particular emphasis on the interaction between participants in communities of practice. The majority of the Masters students in this study are employed as Vocational teachers in Upper Secondary schools and are undertaking the Master program on a part-time basis. The purpose of the study has been to generate new knowledge about cooperation between students, working life and the University College as a step both in further development of the Master's program in Vocational Pedagogy, and to strengthen professional learning. The research question: To what extent is there a link between students initiated cooperation with colleagues and employers compared to what the students actually experience of cooperation? Has the Master thesis (development work) led to development of competence in their work place or just for the students themselves?

Method: The study is based on a quantitative questionnaire conducted at Oslo and Akershus University College of Applied Sciences, Institute of Vocational Teacher Education. The respondent selection consisted of 84 part time students on the Master program in Vocational Pedagogy in the academic years 2009 to 2012. The response rate was 55\%. The collected data was analyzed by using regression and reliability analysis. The purpose of the questionnaire was to find out the extent to which students generally initiated cooperation with colleagues and whether there is a link between the extent of their initiative and their experience of the cooperation. The data obtained by the questionnaire is based on the students' own reflections and experiences of the cooperative processes with their colleagues and employers.

The results show a statistical correlation between the students' own initiative and experience of cooperation with colleagues or employers, that is to say that a colleague or manager has participated in the research work: for example with data collection, by making his or her teaching available in the research or by having participated in the analysis of the results, reflection and discussions. The tests show that this only occurs to a very limited extent. There are other factors that are involved and these are not considered as variables in the study.

Although the students have taken initiative to cooperate with leaders and colleagues in their workplace they experience only a limited degree of cooperation with them.

Furthermore, the results show that the knowledge gained by the individual students is seldom shared with their colleagues at work / community of practice.

Conclusion: The study concludes that there is a correlation between students' initiated cooperation and students' experience of cooperation with colleagues and employers. Still, it cannot be taken for granted that colleagues and employers will be interested even if students 
take the initiative to cooperate. The findings highlight continued research on other relevant forms of cooperation, where Master degree students in Vocational pedagogy find partners outside and not within their own work place.

Keywords: vocational teacher education and training, collaborative teachers, learning, learning organization 


\section{Innledning}

Hensikten med studien har vært å utvikle ny kunnskap om samarbeid mellom studentene, arbeidslivet og høgskolen, som et ledd i videre utvikling av masterstudiet i yrkespedagogikk, og å styrke profesjonslæringen (Hiim, 2013; Hiim \& Hippe, 2001; Raaen, 2010). Resultatene skal bidra til ny kunnskap og $\varnothing \mathrm{kt}$ forståelse for viktigheten av samarbeidet mellom studentene og arbeidslivet under studiene. Den skal føre til bedre tilretteleggelse av masterstudiet gjennom ny kunnskap basert på studentenes egne erfaringer. Begrepene arbeidsliv, ansatte og arbeidsgivere, handler i denne artikkelen om deltidsstudentenes egne arbeidsplasser og kolleger f.eks. skolens ansatte som lærerne og skoleorganisasjonen med skoleledere.

I masterstudiet skal studentene i samarbeid og dialog med andre, reflektere og analysere erfaringer og utvikle ny kunnskap i hermeneutiske spiralprosesser (Gadamer, 1989; Gilje, 1987). Utgangspunktet for teoristudier, diskusjoner og veiledning er studentenes erfaringer knyttet til deres egne prosjekter, og kunnskapsutviklingen drives gjennom studentenes faglige interesser. Gjennom erfaringslæring (Kolb, 1984), i et godt samarbeid mellom studenter og kollegaer, vil det være mulig å gjøre studentenes forskning mer i samsvar med samfunnets behov for kompetanse og profesjonsutviklingen. Begrepet erfaringslæring i denne artikkelen og i yrkespedagogikk-studiene er fundamentert på Eksemplarisk læring (Illeris, 1981; Negt, Weber, Steen Nielsen \& Salling Olesen, 1997), Konfluentpedagogikk (Grendstad \& Sandven, 1986), Prosjektprosesser (Berthelsen, Illeris \& Poulsen, 1988), Refleksjonsspiralen til Kolb (1984), Frigjøringspedagogikken til Freire (1999) og Deweys "Learning by doing” (2005).

Tidligere forskning (Hovdehaugen, Frøseth \& Aamodt, 2010; Høie, 2008, 2010) har vist at samarbeidet på egen arbeidsplass ikke utøves i så stor grad som ønskelig. Ofte snakkes det om læreren som en individuell tenker og ikke som en person som tenker og handler i samarbeid med andre (Engeström, 1994). Det fokuseres lite på den profesjonsutviklingen og læringen som kan skje, gjennom organisert pedagogisk virksomhet og kollegaveiledning, og hvor hensikten er «å gjøre hverandre gode», ved å bidra i hverandres profesjonelle utvikling (Raaen, 2010). I en slik kultur kan det være vanskelig å ta initiativ og invitere ledere, kolleger og andre inn i sitt lærings- og forskningsarbeid. Det kan være vanskelig for masterstudentene som opplever å være i en slik kultur, å ta initiativ fordi de da bryter med det eksisterende og det ikke finnes tilstrekkelig frirom i organisasjonen (Nielsen, Nielsen, Munk-Madsen \& Hartmann-Petersen, 2010; Schwencke \& Larsen, 2011). Forankringen (Innbjør \& Kleiveland, 2007) må da skje over tid, og tidsaspektet for prosessen har kanskje ikke studentene tenkt over, hvis de ikke har vurdert dette tidlig og lagt det inn i sin planlegging. 


\section{Programplan for master i yrkespedagogikk}

I programplanen for masterstudiet i yrkespedagogikk (Høgskolen i Oslo og Akershus, 2013) står det klart at studentene skal bidra til utvikling og kunne lede utviklingsprosesser i samarbeid med andre gjennom egen erfaring og refleksjon. Samarbeidslæring og eksemplarisk læring (Illeris, 1981; Weber, Olesen \& Nielsen, 1997) er vesentlig i studiet som i stor grad baseres på erfaringslæring. Erfaringslæring er et overordnet og mangesidig begrep, og i begrepet kan det ligge en dobbel betydning som kombinerer akkumulert kognitiv kunnskap med individets opplevelse (Dewey, 2008; Knudsen et al., 1999; Kolb, 1984). Studentenes erfaringer må være vesentlige, innholdsmessig og erkjennelsesmessig, og må ha betydning for dem selv. Videre må det et vesentlig psykodynamisk element til, det må være følelsesmessig engasjerende. Dessuten må det være et vesentlig sosialt og samfunnsmessig element, som vedrører en selv og den omverden man lever i (Knudsen et al., 1999). Dette vil også gjelde for dem som skal samarbeide med studenten og deres motivasjon. Negts begrep om «eksemplarisk læring» (Weber et al., 1997) blir et særlig meningsfylt utgangspunkt i yrkespedagogikken der et av fundamentene i studiet er gjennomføring av utviklingsforskning.

Det er viktig at studentene opplever samarbeid, gjør seg erfaringer i samarbeidsprosesser både internt og eksternt $\mathrm{i}$ arbeidslivet, og utvikler sin samarbeidskompetanse.

Utgangspunktet for denne artikkelen er min egen refleksjon om at det gjennom $\varnothing \mathrm{kt} \mathrm{kollegialt}$ samarbeid og utvikling av samarbeidskompetanse, vil kunne skapes større åpenhet og interesse for endring. Større åpenhet kan bidra til økt kompetanseutvikling for studentene og kollegene, samt til innovasjon i profesjonsutøvelsen (Raaen, 2010). Et godt samarbeid med kolleger vil kunne styrke masterprosjektets relevans i forhold til utvikling av fag og yrkesopplæring, som er en sentral del i profesjonsutdanningen for yrkesfaglærere (YFL).

\section{Kultur for samarbeid}

Livslang læring er et overordnet prinsipp i den norske kunnskapspolitikken og omfatter all målbevisst læringsaktivitet livet gjennom. I et arbeids- og samfunnsliv som gjennomgår hyppige omstillinger, er evnen til å tilegne seg ny kunnskap og nye ferdigheter avgjørende for å sikre konkurransedyktige virksomheter og gode velferdstjenester. En politikk som gjør at hele befolkningens kompetanse kan brukes og videreutvikles, er et viktig grunnlag for et fortsatt sterkt velferdssamfunn. St.meld. nr. 44 (2008-2009) Utdanningslinja legger til grunn at livslang læring er et premiss for å lykkes med arbeidslinja i norsk velferdspolitikk og i Meld. St. nr. 13 Utdanning for velferd (2011-2012), er samspillet mellom utdanning og 
yrkesfelt problematisert, og det foreslås videre utvikling i forhold til dagens situasjon. I meldingen argumenteres det blant annet for en tyngdeforskyving mot praksis med både mer, bedre og relevant praksis i utdanningene og bedre samhandling mellom utdanningene og praksisfeltene.

For elevenes læringsmiljø- og resultater har kompetansen til lærere og skoleledere stor betydning. Kompetanse og utviklingstiltak for disse er en viktig prioritering for regjeringen. Ambisjonen om å utvikle skolen til en lærende organisasjon og samfunnets forventninger til skolen, har ført til økte krav til skoleledelse. Mange beslutningsoppgaver er delegert til skoleledere i Norge. Mange rektorer oppgir i TALIS-unders $\emptyset$ kelsen 2008 (Utdanningsdirektoratet, 2009), at de administrative og pedagogiske ledelsesoppgavene i hverdagen glir over i hverandre, og at de ikke ser noe klart skille mellom oppgavene. Flere skoleledere mener også at de administrative oppgavene naturlig bygger opp under pedagogiske ledelsesoppgaver (Meld. St. 20, 2012-2013). I en tid hvor elevene bruker mer og mer tid på skolen, vil lærere og ledelse møte utfordringer som de sammen må håndtere. Å utvikle en skole til en lærende organisasjon krever samarbeid og vilje hos både lærere og ledelse, påpekes det i St.meld.20:

Målene for skolens virksomhet kan ikke nås dersom skolen ikke mobiliserer de ansattes samlede kompetanse. Det stilles krav til faglig samarbeid. I et kollegialt fellesskap vil ulik fagkompetanse og spesialisering hos lærerne være en styrke. Gode lærere er aktive bidragsytere i et profesjonelt faglig fellesskap som utvikler skolen som en lærende organisasjon (Meld. St. 20, 2012-2013, s. 158).

Mulighet for utvikling av yrkesfaglærerens kompetanse i organisasjonen er derfor ikke bare et ønske for den enkelte, men et kriterium for å oppnå nasjonale mål og skolen som en lærende organisasjon. Engeström (1994) skriver at det oftest snakkes om læreren som en individuell tenker og ikke som en person som tenker og handler i samarbeid med andre. Det fokuseres lite på den profesjonsutviklingen og læringen som kan skje gjennom organisert pedagogisk virksomhet og kollegaveiledning, hvor hensikten er «å gjøre hverandre gode» ved å bidra i hverandres profesjonelle utvikling (Raaen, 2010). I en slik kultur kan det være vanskelig å ta initiativ til samarbeid, og det er viktig å forankre (Innbjør \& Kleiveland, 2007) samarbeidet hos ledere og kolleger.

\section{Samarbeid mellom masterstudenter, kolleger og ledere under utdanning}

Ved høgskolen i Oslo og Akershus utdanner masterstudiet i yrkespedagogikk studenter som skal delta $\mathrm{i}$ et bredt arbeidsliv, i skole og arbeidsliv. Forskningen på feltet kan derfor være 
relevant for mange også utenfor skolen, slik som arbeidslivsorganisasjoner, fylkespolitikere og andre som arbeider med utfordringer knyttet til yrkes- og profesjonskompetanse.

Masterstudiet rekrutterer studenter som i hovedsak er yrkesfaglærere ved utdanningsprogrammene i den videregående skolen, men også lærere fra andre profesjonsstudier samt tilsatte i privat og offentlig sektor med arbeid innen fag- og yrkesopplæring.

I forskningsarbeidet Mastergrad i yrkespedagogikk 2003-2009 viser resultatene at kunnskapen i betydelig grad blir hos studenten og formidles i liten grad videre til andre etter avsluttet studie. Det er fremdeles mange arbeidsgivere som tar en passiv rolle og studentene opplever i liten grad å ha erfart faglig støtte og interesse for sitt masterarbeid (Høie, 2008, 2010). Disse resultatene ble formidlet til nye studenter, og det ble lagt vekt på betydningen av studentenes eget engasjement og initiativ til å samarbeide med kolleger og ledere. Om dette har ført til et bedre samarbeid, ønsker jeg å få belyst i denne artikkelen.

\section{Problemstilling}

I hvilken grad er det sammenheng mellom studentenes initiativ til samarbeid og studentenes erfarte samarbeid med kolleger og arbeidsgiver? Har masteroppgaven fфrt til kompetanseutvikling på egen arbeidsplass eller kun for studentens egen utvikling?

\section{Forskningsspørsmål}

1) I hvilken grad har tidligere masterstudenter i yrkespedagogikk tatt initiativ til samarbeid med kolleger og arbeidsgiver om sin masteroppgave?

2) Hvordan har tidligere masterstudenter erfart samarbeid med kolleger og arbeidsgiver under arbeidet med sin masteroppgave?

3) Hvilken nytte har arbeidsplassen og studentene hatt av masterprosjektet med tanke på kompetanseutvikling på egen arbeidsplass 


\section{Metode og litteratursøk}

Data i artikkelen er basert på et litteraturs $\varnothing \mathrm{k}$ (Patton, 2002) og en surveyunders $\varnothing \mathrm{kelse}$ (Grønmo, 2004). Studien er teoretisk forankret i kognitiv- og sosialkonstruktivistiske læringsteorier (Bakke \& Tønnesen, 2007; Kjørup, 2008), hvor det fokuseres på deltakernes individuelle opplevelser av læringsprosessen, med særlig vekt på samspillet mellom aktørene i praksisfellesskapet (Bakke \& Tønnesen, 2007; Dewey, 2005; Dysthe, 2001; Hiim, 2013; Hiim \& Hippe, 2013; Wenger, 2009). Studien tok utgangspunkt i Mette Høies tidligere forskning Mastergrad i yrkespedagogikk 2003-2009: en oppfølgingsunders $\phi k e l s e$ (2010). Litteraturs $\varnothing \mathrm{k}$ ble benyttet som metodisk tilnærming i artikkelen som beskrevet i Patton (2002). Søkene ble utført i august 2015 i søkekildene Oria og ERIC. Følgende søkeord med variasjoner ble valgt: lærende organisasjon* (trunkering), yrkespedagog*, læring på arbeidsplassen, læring* og lærer* i den norske basen og higher education, vocational education, cooperating teacher*, internship, mentor*, studies, work place learning i den internasjonale basen. Videre ble søket avgrenset til perioden 2000-2015. Av samtlige treff som søket genererte, ble til sammen seks publikasjoner inkludert i artikkelen.

\section{Surveyundersøkelsen}

Studien bygger på kvantitativ respondentdata som ble innhentet gjennom en surveyundersøkelse, basert på et strukturert spørreskjema med faste spørsmål og svaralternativer gitt i vurderingsskala 1(ikke i noen grad) - 6 (i meget stor grad) (Grønmo, 2004). Hensikten med spørreundersøkelsen var å kartlegge i hvilken grad studentene generelt sett tok eget initiativ til å samarbeide med kolleger, og om det kan sies å være en sammenheng mellom grad av initiativ og erfart samarbeid. Dataene som fremkommer gjennom spørsmålene er basert på studentenes egne refleksjoner og opplevelser av samarbeidsprosessen med kolleger og arbeidsgiver.

\section{Populasjon, utvalg og svarprosent}

Respondentene er 84 studenter ved YFL som har avlagt sin mastergrad i perioden 2009- 2012, dette var det totale antall studenter som avla eksamen i den perioden. Alle er inkludert i

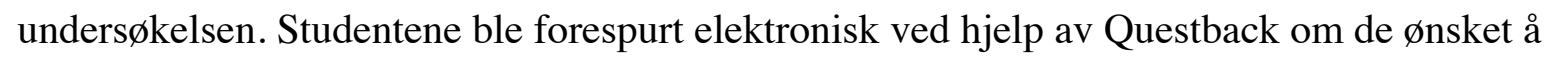
delta i undersøkelsen, og det ble gjennomført en utsendelse inkl. to purringer.

Datainnsamlingen ble avsluttet 18.10.2013, svarprosenten var 55\%. 


\section{Utforming av spørreskjema og analyse}

Spørreskjemaet hadde som mål å belyse i hvilken grad det er sammenheng mellom studentenes initiativ til samarbeid og studentenes erfarte samarbeid med kolleger og arbeidsgiver, og i hvilken grad masteroppgaven har ført til kompetanseutvikling på egen arbeidsplass. Fokus ble satt på samarbeid og initiativ, som her handler om hvordan samarbeidet har foregått på egen arbeidsplass sammen med kolleger og arbeidsgiver, som en del av studentens læringsprosess. Det strukturerte spørreskjemaet inneholdt derfor spørsmål om bakgrunnsdata som alder og arbeidssted, atferdsspørsmål om handlinger, og holdningsspørsmål om erfaringer (Johannessen, Christoffersen \& Tufte, 2010, s. 270). Spørsmål om handlinger fungerer jo mer spesifikke de er og atferdsspørsmålene spør derfor om hva studentene aktivt gjorde for å invitere til samarbeid (Grønmo, 2004, s. 171-172).

Ved utarbeidelse av spørreskjema ble det utført en forhåndsanalyse av tidligere studier (Hiim, 2013; Hiim \& Hippe, 2001; Høie, 2010) og min egen førforståelse. Det var relevant å benytte Høies studie fra 2010 som utgangspunkt for utvikling av spørsmålene, da studien var gjennomført på samme masterstudie og med samme målgruppe som respondenter (Høie, 2010). Dette ga muligheten til å sammenlikne resultatene til en viss grad fra unders $\varnothing$ kelsene. Høies åpne spørsmål og studentenes svar innenfor kategorien; Arbeidsgiver og kollegers rolle i gjennomfфring av mastergradsstudier, ble utgangspunktet for spørsmålsformuleringen for en del av spørreundersøkelsen. I tillegg la jeg inn spørsmål vedrørende studentenes eget initiativ til samarbeid. Spørreundersøkelsen ble derfor delt inn i fire deler, 1) bakgrunnsdata (kull, arbeidstilhørighet, alder), 2) eget initiativ til samarbeid med kollega og arbeidsgiver, 3) erfart samarbeid med kollega og arbeidsgiver og 4) erfart mastergradens betydning for kompetanseutvikling.

I det strukturerte spørreskjema kunne respondentene krysse av for gitte svaralternativer, gradert fra 1-ikke i noen grad til 6 - i meget stor grad. De gitte svaralternativene var valgt ut av forskeren og ga ikke respondentene mulighet til å komme med andre alternativer.

Respondentene kunne derfor bare påvirke resultatene ved å gradere sitt svar fra 1 til 6. Kritisk sett er det derfor mulig at resultatene ville blitt annerledes om undersøkelsen også hadde omfattet åpne spørsmål. På bakgrunn av dette vil det være interessant å gjøre en utdypende kvalitativ undersøkelse senere med utgangspunkt i resultatene fra denne studien. 


\section{Begrepsavklaring for analysen}

I begrepet kompetanseutvikling på egen arbeidsplass legges betydningen; utvikling og endring av egen og/eller arbeidsplassens praksis. Det kan være utviklet nye undervisningsopplegg, nye måter å samarbeide på både internt og eksternt o.a. Det favner bredt med både administrativ og faglig endring, hvor hensikten er å videreutvikle bedre praksis for læring, både for elever og personale i et yrkespedagogisk perspektiv.

Erfart samarbeid vil si at masterstudenten har hatt en kollega med seg i sitt forskningsarbeid. Kollegaens rolle kan være ulik både i omfang og i handling, men i et erfart samarbeid ligger det at studenten har hatt en opplevelse av at en kollega eller arbeidsgiver har deltatt $\mathrm{i}$ forskningsarbeidet. Kollegaen kan blant annet ha bidratt til innhenting av data, kan ha stilt sin klasse eller sin undervisning til disposisjon for forskningen, kan ha deltatt i analyse av resultater eller bidratt til refleksjon og diskusjon omkring resultatene.

I begrepet nytte på arbeidsplassen menes det at studentens forskningsresultater blir brukt eller videreutviklet på arbeidsplassen etter at studenten er ferdig med sitt masterarbeid. Hvis studentens aksjonsforskning kan dokumentere en måte å integrere fellesfag i yrkesfagene på som gir økt læringsutbytte i fellesfaget, vil dette være nyttig for arbeidsplassen om andre kolleger vil benytte metoden videre og evt. videreutvikle den. Hvis ingen kolleger vil benytte metoden, vil vi kunne si at studentenes forskning ikke har vært til nytte for arbeidsplassen og at arbeidsplassen ikke har fremstått som en lærende organisasjon.

I studien brukes begrepet initiativ på studentens egne aktive handlinger for å oppnå samarbeid og interesse for sin masteroppgave. Handlinger i denne sammenhengen vil eksempelvis være å informere om sitt kommende masterarbeid og invitere kolleger til å samarbeide i ulik grad. Personalmøter kan være en mulig arena for dette, eller studenten kan ta direkte kontakt med kolleger som de samarbeider faglig med ellers, eller som de tror kan ha interesse for masterprosjekts tema.

\section{Etisk vurdering og validitet}

Prosjektet er meldt NSD (prosjekt 38215), innhenting og behandling av data ble foretatt i henhold til nasjonale etiske retningslinjer og anbefalinger gitt av NSD. Troverdighet, styrke og overførbarhet av kunnskap beskrives av begrepene reliabilitet, validitet og generaliserbarhet (Kvale \& Birkmann, 2009, s. 246). Validitet kan deles inn i ulike former for validitet, i denne studien er den pragmatiske validiteten høy. Datamateriale viser 
sammenhengen mellom empirien og de handlingene som det legges vekt på å utvikle. Studien er valid fordi den gir resultater som kan føre til endringer av praksis som anvendt forskning. Studien er begrenset til kun å gjelde deltidsstudenter på masterstudiet i yrkespedagogikk på HiOA, som avla eksamen i perioden 2009-2012, og deres samarbeidsrelasjoner mellom kolleger og ledere på egen arbeidsplass. Den kan ha overføringsverdi til tilsvarende studieløp, men validiteten er begrenset til dette studieløpet.

Studien har en hermeneutisk tilnærming (Grønmo, 2004, s. 373). Forskerens førforståelse utviklet gjennom lang erfaring fra undervisning som yrkesfaglærer og som førstelektor i yrkespedagogikk, har preget både utforming av spørsmål, analyse og fortolkning (Johannessen et al., 2010). Kjennskap til forskningsfeltet gjennom erfaring fra veiledning på masterstudiet, gir forskeren kvalifikasjoner som styrker kompetansevaliditet (Grønmo, 2004, s.234).

\section{Resultat og diskusjon}

Resultatene fra den kvantitative tilnærmingen og litteratursøket presenteres og diskuteres ut i fra to bakgrunnsspørsmål og de sju hovedspørsmålene som ble stilt i spørreundersøkelsen .

\section{Bakgrunnsdata}

I perioden 2009- 2012 avla totalt 84 masterstudenter sin eksamen i yrkespedagogikk ved HiOA. Alle studentene ble inkludert i denne studien og 46 studenter responderte på spørreundersøkelsen. Dette tilsvarer 55\% og viser et stort frafall av respondenter. I ettertid ser jeg at det ville vært relevant å studere frafall av respondenter i relasjon til bakgrunn, alder, utdanning og kjønn. Det kunne bidratt til å belyse årsaker og sammenhenger relatert til frafallet. En årsak til noe av det store frafallet av respondenter kan være at studentenes tidligere mailadresser, ikke lenger var aktive. Mailadressene til respondentene ble hentet fra studentarkivet på HiOA. Svarprosenten må derfor vurderes ut ifra dette, og den reelle svarprosenten kan være høyere blant de som faktisk mottok undersøkelsen. 
Oversikt over fordelingen av respondentenes arbeidssted under studiet

\begin{tabular}{|l|c|c|}
\hline Arbeidssted & antall & prosent \\
\hline videregående skole & 30 & 65.2 \\
\hline høgskole/universitet & 4 & 8.7 \\
\hline privat bedrift & 2 & 4.3 \\
\hline offentlig sektor & 10 & 21.7 \\
\hline Total & 46 & 100.0 \\
\hline
\end{tabular}

Studentenes arbeidssted fordeler seg på videregående skole med den største delen, 30 studenter har sitt daglige arbeid der, mens $10 \mathrm{i}$ offentlig sektor. Det er forholdsvis få fra Høgskole og universitet og privat sektor.

Tabell 2

Respondentenes alder ved avlagt mastergrad

\begin{tabular}{|l|c|c|c|}
\hline Alders intervall & antall & prosent & akkumulert prosent \\
\hline $26-35$ & 3 & 6.5 & 6.5 \\
\hline $36-45$ & 9 & 19.6 & 26.1 \\
\hline $46-55$ & 25 & 54.3 & 80.4 \\
\hline $56-65$ & 9 & 19.6 & 100.0 \\
\hline Total & 46 & 100.0 & \\
\hline
\end{tabular}

Dette viser at $80.4 \%$ av respondentene var opptil 55år da de avla sin mastergrad. Av disse var gruppen 46-55 år størst med 54.3\%. 19.6\% var mer enn 55 år og minst var gruppen 2635 år, de utgjorde kun $6.5 \%$ av respondentene.

I undersøkelsen til Høie (2010), utgjorde studentene i aldersgruppen opptil 55 år 78,2 \%. I denne studien utgjorde aldersgruppen 80,4\%. Interessant er det å merke seg at ved å slå sammen de to yngste gruppene, vises det at aldersgruppen 26-45år utgjør 32,6 \% av respondentene, tilsvarende for Høies undersøkelse i 2010 var $25 \%$. Det kan bety at studiet i dag rekrutterer yngre studenter enn tidligere. 


\section{Studentenes eget initiativ til samarbeid med kollega og arbeidsgiver}

Spørsmål 1. ’I hvilken grad tok du initiativ til å samarbeide med kollegaer ved å ...?"

Tabell 3

Viser grad av studentenes initiativ til samarbeid med kolleger

\begin{tabular}{|l|l|l|l|l|l|l|l|}
\hline & $\begin{array}{l}\mathbf{1} \\
\text { ikke }\end{array}$ & $\mathbf{2}$ & $\mathbf{3}$ & $\mathbf{4}$ & $\mathbf{5}$ & $\begin{array}{l}\mathbf{6} \text { meget } \\
\text { stor } \\
\text { grad }\end{array}$ & $\mathbf{~ N ~}$ \\
\hline $\begin{array}{l}\text { fortelle om masteroppgaven } \\
\text { din underveis i arbeidet }\end{array}$ & $8,7 \%$ & $8,7 \%$ & $15,2 \%$ & $15,2 \%$ & $\mathbf{2 1 , 7 \%}$ & $\mathbf{3 0 , 4 \%}$ & 46 \\
\hline $\begin{array}{l}\text { spørre om en kollega } \text { nsket } \\
\text { å bidra på en eller annen } \\
\text { måte i ditt prosjekt }\end{array}$ & $6,5 \%$ & $10,9 \%$ & $6,5 \%$ & $17,4 \%$ & $\mathbf{1 9 , 6 \%}$ & $\mathbf{3 9 , 1 \%}$ & 46 \\
\hline $\begin{array}{l}\text { presentere masteroppgaven } \\
\text { med tema etc. på } \\
\text { personalmøter el. I på din } \\
\text { arbeidsplass }\end{array}$ & $26,1 \%$ & $10,9 \%$ & $6,5 \%$ & $13,0 \%$ & $23,9 \%$ & $19,6 \%$ & 46 \\
\hline $\begin{array}{l}\text { tilby andre å bruke } \\
\text { resultatene fra din } \\
\text { masteroppgave i sitt eget } \\
\text { arbeid }\end{array}$ & $6,5 \%$ & $6,5 \%$ & $13,0 \%$ & $17,4 \%$ & $32,6 \%$ & $23,9 \%$ & 46 \\
\hline
\end{tabular}

Tabell 3 viser at studenten tar betydelig initiativ til samarbeide med kolleger gjennom å fortelle om sitt arbeid, invitere kolleger til å bidra i et samarbeide, samt tilby sine resultater som ressurs til andres arbeid. Ved å se på verdiene 5 og 6 under ett, ser vi at nær $55 \%$ mener å ha formidlet sitt arbeid underveis på arbeidsplassen i stor grad, omtrent $60 \%$ mener i stor grad å ha invitert kolleger til å samarbeide i prosjektet. Tabellen viser at studentene selv mener at de i forholdsvis liten grad har tatt initiativ til å presentere tema for sitt mastergradsarbeid på for eksempel personalmøter på arbeidsplassen. På dette punktet skiller studentenes initiativ seg fra de tre andre variablene. 
Spørsmål 2. "I hvilken grad tok du initiativ til å snakke med din arbeidsgiver om ...?"

Tabell 4

Viser grad av studentenes initiativ til å snakke med arbeidsgiver om sitt masterstudie

\begin{tabular}{|c|c|c|c|c|c|c|c|}
\hline & $\begin{array}{l}1 \\
\text { ikke }\end{array}$ & 2 & 3 & 4 & 5 & $\begin{array}{l}6 \\
\text { meget } \\
\text { stor }\end{array}$ & $\mathbf{N}$ \\
\hline $\begin{array}{l}\text { at du skulle } s \varnothing \mathrm{ke} \\
\text { masterstudie }\end{array}$ & $15,2 \%$ & $2,2 \%$ & $2,2 \%$ & $13,0 \%$ & $13,0 \%$ & $54,3 \%$ & 46 \\
\hline $\begin{array}{l}\text { organisatoriske rammer for } \\
\text { studiet }\end{array}$ & $8,7 \%$ & $4,3 \%$ & $15,2 \%$ & $15,2 \%$ & $21,7 \%$ & $34,8 \%$ & 46 \\
\hline $\begin{array}{l}\emptyset \text { nske om tilrettelagte } \\
\text { rammer under studiet }\end{array}$ & $10,9 \%$ & $4,3 \%$ & $15,2 \%$ & $15,2 \%$ & $17,4 \%$ & $37,0 \%$ & 46 \\
\hline $\begin{array}{l}\text { arbeidsgiver hadde et } \\
\varnothing \text { nske for din } \\
\text { masteroppgaves tema }\end{array}$ & $43,5 \%$ & $\begin{array}{l}19,6 \\
\%\end{array}$ & $13,0 \%$ & $6,5 \%$ & $2,2 \%$ & $15,2 \%$ & 46 \\
\hline
\end{tabular}

Tabell 4 viser studentenes initiativ til å snakke med arbeidsgiver om deltagelse på studiet og emne for masteroppgaven, tilrettelegging og økonomisk støtte under studiet. Det er interessant at kun $15 \%$ mener selv å ha i stor grad spurt arbeidsgiver om ønsket tema for masterprosjektet. Resultatene kan oppsummeres til at masterstudentene i stor grad hadde tatt initiativ til å snakke med sin arbeidsgiver om at de skulle søke opptak på masterstudiet. Hele

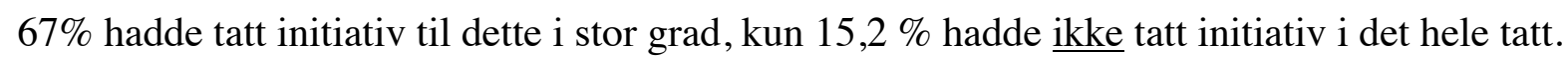
Svarene fra de andre variablene i denne gruppen viser, at omtrent 50\% mener de i stor grad snakket om organisatoriske rammer ved studiet og ønske om tilrettelagte rammer med sin arbeidsgiver. Igjen viser disse resultatene, at studentene tar initiativ i stor rad til å snakke med arbeidsgiver om rammene for sitt masterstudie. Det er et spørsmål som skiller seg fra de andre, og der viser resultatet at 43,5\% ikke har snakket med arbeidsgiver om tema for masteroppgaven. Legger vi summen av de to laveste verdiene 1 og 2 sammen, viser det at over $60 \%$ ikke, eller i svært liten grad, har snakket med sin arbeidsgiver om tema for masteroppgaven.

Eget initiativ er en vesentlig faktor for samarbeidet, og det kan virke innlysende at det er en sammenheng mellom eget initiativ og erfart samarbeid. Resultatene viser at studentene i stor grad har informert kolleger om sitt masterarbeid under studiet. Kun 6,5\% hadde ikke tatt initiativ i det hele tatt til dette. Resultatene fra de andre spørsmålene i samme variabel viser at nær 60\% har spurt kolleger om de ønsker å være med i arbeid i masterprosjektet, 56,5\% har i stor grad tilbudt kolleger å benytte resultatene fra prosjektet i sitt eget arbeid, kun 6,5\% har ikke spurt om dette. Kun et av spørsmålene i gruppen under denne variabelen, skilte seg fra denne tendensen. Hele 26,1\% hadde ikke tatt eget initiativ til å legge frem presentasjon av sitt 
arbeid på egen arbeidsplass. Dette er interessant, fordi de på den ene siden tar stor grad av initiativ til å samarbeide underveis, mens de på den andre siden ikke tar initiativ til å formidle resultatene av arbeidet videre til kolleger. Hva kan dette komme av?

Forskning viser at manglende støtte fra kolleger gir negativ effekt på egen mestringsopplevelse. Hvis studenten i liten grad har erfart respons og interesse for sitt arbeid gjennom kollegene, vil det nok kunne redusere lysten til å presentere arbeidet underveis og i etterkant. Hvis kulturen for profesjonelt lærerarbeid på arbeidsplassen er at lærerne utøver sitt arbeid som en individuell prosess, og at den unders $\varnothing$ kende og reflekterende praksis i liten grad er tilstede, vil det være en større utfordring å formidle sine resultater og sitt arbeid til kollegiet. For å oppnå samarbeid med kolleger er det viktig å ha forankret arbeidet hos arbeidsgiver. I det perspektivet er det interessant at kun 15\% i stor grad har spurt arbeidsgiver om ønsket tema for masterprosjektet. Hva kan være årsaken til dette?

De snakker gjerne med arbeidsgiver om rammer for tilrettelegging og økonomi under studiet, og erfarer også å bli møtt med støtte på disse områdene, mens de kanskje kvier seg for å ta opp det faglige, som her kan være å ta opp skolens pedagogiske utfordringer, behov for utvikling og områder for utviklingsarbeid og forskning. Engeström (1994) skriver at det oftest snakkes om læreren som en individuell tenker og ikke som en person som tenker og handler i samarbeid med andre. Hvis det ikke er kultur for samarbeid på arbeidsplassen, vil det heller ikke oppleves som naturlig og kanskje heller ikke som interessant å diskutere tema med arbeidsgiveren. Hvis det fokuseres lite på den profesjonsutviklingen og læringen som kan skje gjennom organisert pedagogisk virksomhet og kollegaveiledning, hvor hensikten er «å gjøre hverandre gode» ved å bidra i hverandres profesjonelle utvikling (Raaen, 2010), kan det i en slik kultur være vanskelig å ta initiativ til samarbeid og forankring. Innbjør og Kleiveland (2007) legger stor vekt på betydning av forankring på flere nivå når samarbeid mellom ledere og kolleger skal fremmes.

Sett i et organisasjonsperspektiv kan det være vanskelig å gå inn i et organisert samarbeid fordi det ikke er en selvfølge at arbeidsgiver og studenten i dette tilfelle, har samme interesse. Forskning og utviklingsarbeid genererer resultater som kan være utfordrende og ikke alltid $\emptyset n s k e l i g$ i et ledelsesperspektiv, hvor arbeidsgiver slites mellom personalledelse, pedagogisk ledelse og økonomisk drift. Dette kan være med på å redusere lærernes og studentens frirom (Nielsen et al., 2010; Schwencke \& Larsen, 2011). Med frirom menes ikke bare tid og sted for utvikling, men trygghet for å skape, innovasjon og eksperimentering. Det viser seg at lærere 
som får støtte i utviklingsprosesser gjennom å reflektere sammen med andre, er mer villige til å eksperimentere og gjennomføre utviklingsprosesser (Raaen, 2010; Wan, Yang, Cheng \& Su, 2013). Man kan derfor også stille spørsmålet; I hvilken grad er studentenes initiativ til samarbeid avhengig av arbeidsgivers og kollegers kultur for læring på arbeidsplassen?

\section{Studentenes erfarte samarbeid med kollega og arbeidsgiver}

Spørsmål 3. "I hvilken grad erfarte du at din arbeidsgiver tilrettela for gjennomføringen av studiet?"

Tabell 5

Viser grad av studentenes erfarte arbeidsgivers tilretteleggelse for studiet

\begin{tabular}{|c|c|c|c|c|c|c|c|}
\hline & $\begin{array}{l}1 \\
\text { ikke }\end{array}$ & 2 & 3 & 4 & 5 & $\begin{array}{l}6 \\
\text { meget } \\
\text { stor }\end{array}$ & $\mathbf{N}$ \\
\hline $\begin{array}{l}\text { la praktisk til rette for } \\
\text { studiedeltagelse }\end{array}$ & $17,4 \%$ & $13,0 \%$ & $10,9 \%$ & $13,0 \%$ & $17,4 \%$ & $28,3 \%$ & 46 \\
\hline $\begin{array}{l}\text { la } \varnothing \text { konomisk til rette for } \\
\text { studiedeltagelse }\end{array}$ & $32,6 \%$ & $17,4 \%$ & $6,5 \%$ & $8,7 \%$ & $13,0 \%$ & $21,7 \%$ & 46 \\
\hline $\begin{array}{l}\text { informerte kolleger om } \\
\text { min masteroppgave }\end{array}$ & $37,0 \%$ & $17,4 \%$ & $13,0 \%$ & $10,9 \%$ & $13,0 \%$ & $8,7 \%$ & 46 \\
\hline ga personlig st $\varnothing$ tte & $21,7 \%$ & $23,9 \%$ & $15,2 \%$ & $17,4 \%$ & $13,0 \%$ & $8,7 \%$ & 46 \\
\hline ga faglig støtte & $39,1 \%$ & $23,9 \%$ & $17,4 \%$ & $15,2 \%$ & $2,2 \%$ & $2,2 \%$ & 46 \\
\hline $\begin{array}{l}\text { bidro til å knytte } \\
\text { masteroppgaven min til } \\
\text { min yrkespraksis }\end{array}$ & $32,6 \%$ & $26,1 \%$ & $17,4 \%$ & $6,5 \%$ & $10,9 \%$ & $6,5 \%$ & 46 \\
\hline $\begin{array}{l}\text { bidro til å sikre at min } \\
\text { masteroppgave ble } \\
\text { relevant for } \\
\text { arbeidsplassen }\end{array}$ & $39,1 \%$ & $23,9 \%$ & $13,0 \%$ & $6,5 \%$ & $10,9 \%$ & $6,5 \%$ & 46 \\
\hline
\end{tabular}

Tabell 5 viser grad av studentenes erfarte tilretteleggelse fra arbeidsgiver under gjennomføringen av studiet. Resultatene viser at arbeidsgiver bidrar i en viss grad til å legge praktisk til rette og 34,7 \% har fått økonomisk støtte. Nær 60\% har erfart ingen eller svært liten faglig støtte eller bidrag fra arbeidsgiver til å gjøre masteroppgaven relevant for arbeidsplassen og videre praksis for studenten. 
Spørsmål 4. "I hvilken grad erfarte du dine kollegers betydning for gjennomføring av studiet ved at ...?"

Tabell 6

Viser grad av studentenes erfarte betydning av kollegers samarbeid

\begin{tabular}{|l|l|l|l|l|l|l|l|}
\hline & $\begin{array}{l}\mathbf{1} \\
\text { ikke }\end{array}$ & $\mathbf{2}$ & $\mathbf{3}$ & $\mathbf{4}$ & $\mathbf{5}$ & $\begin{array}{l}\mathbf{6} \\
\text { meget } \\
\text { stor }\end{array}$ & $\mathbf{N}$ \\
\hline $\begin{array}{l}\text { de var interessert i min } \\
\text { masteroppgave }\end{array}$ & $17,4 \%$ & $8,7 \%$ & $21,7 \%$ & $21,7 \%$ & $17,4 \%$ & $13,0 \%$ & 46 \\
\hline $\begin{array}{l}\text { de st } \varnothing \text { ttet meg i mitt } \\
\text { arbeid med } \\
\text { masteroppgaven }\end{array}$ & $17,4 \%$ & $13,0 \%$ & $21,7 \%$ & $17,4 \%$ & $17,4 \%$ & $13,0 \%$ & 46 \\
\hline $\begin{array}{l}\text { de samarbeidet aktivt } \\
\text { med meg i mitt arbeid } \\
\text { med masteroppgaven }\end{array}$ & $\mathbf{3 2 , 6 \%}$ & $\mathbf{1 3 , 0} \%$ & $10,9 \%$ & $19,6 \%$ & $6,5 \%$ & $17,4 \%$ & 46 \\
\hline $\begin{array}{l}\text { de anvendte } \\
\text { resultatene fra min } \\
\text { masteroppgave i sitt } \\
\text { eget arbeid }\end{array}$ & $32,6 \%$ & $21,7 \%$ & $10,9 \%$ & $21,7 \%$ & $4,3 \%$ & $8,7 \%$ & 46 \\
\hline
\end{tabular}

Tabell 6 viser at 45\% av studentene i svært liten grad erfarte aktivt samarbeid med kolleger, kun $13 \%$ har erfart at deres kolleger i stor grad bruker deres mastergradsarbeid. Resultatene viser ingen tydelig tendens for variablene; erfart støtte og interesse for arbeidet.

Gjennom årene har man erfart at studentene har veldig ulike forhold under sin tid som masterstudenter. For enkelte studenter legger arbeidsgiver til rette både økonomisk og praktisk. Andre studenter må selv koste alt og organisere seg med andre for å få mulighet til å fullføre studiet (Høie, 2010). Når det gjelder faglig samarbeid og interesse for studentens mastergradsarbeid, viser denne studien at studentene i svært liten grad erfarer faglig samarbeid med arbeidsgiver og kolleger. Selv om de i stor grad hadde tatt initiativ til å snakke om sitt arbeid med arbeidsgiver, erfarte kun 17,4\% at arbeidsgiver bidro i stor grad til at masteroppgaven ble relevant for arbeidsplassen. Hele $63 \%$ mente at arbeidsgiver ikke eller i svært liten grad, bidro til å gjøre masteroppgaven relevant for arbeidsplassen. Sammenlignet med Høies forskning i 2010 hvor resultatet var 53\%, ser det ikke ut til at denne tendensen har endret seg positivt. Resultatene fra de andre spørsmålene i denne gruppe viser at arbeidsgiver bidrar lite faglig. 63\% erfarte liten eller ingen grad av faglig støtte. Unntaket er økonomisk st $\varnothing$ tte, der viser det at 34,7 \% har erfart stor grad av økonomisk støtte. Det kan se ut som faglig oppfølging og støtte fra arbeidsgiver har $\varnothing \mathrm{kt}$ noe fra 2010 til i dag, men at $\varnothing$ konomisk støtte er redusert, hvis vi sammenligner med undersøkelsen i 2010 (Høie, 2010). 
Når det gjelder betydning av samarbeid med kolleger, kan det oppsummeres med at $45 \%$ av masterstudentene i svært liten grad erfarte at kolleger har hatt betydning for gjennomføring av studiet, ved aktivt samarbeid om masterprosjektet. Også her viser studien en endring fra undersøkelsen i 2010 hvor resultatet viste 53\% på samme spørsmål. Økt innsats fra utdanningen under studietiden om betydningen av samarbeid på egen arbeidsplass, kan være en av årsakene til denne positive endringen.

Det er viktig for studentenes kompetanseutvikling og for utviklingen i skolen at lærere samarbeider om utvikling og endring. Måten det samarbeides på og holdninger til samarbeid virker inn på den kulturen som skapes for profesjonslæring (Raaen, 2010; Wan et al., 2013). Trivsel er en viktig faktor i å styrke studentenes engasjement for sitt yrke. Deltagelse i et praksisfellesskap bidrar til å berike studentenes yrkeskompetanse, forbedrer deres personlige vekst, og refleksjon over deres praksisopplevelser i form av profesjonelle muligheter (Wan et al., 2013). Likevel vil ikke enhver samarbeidsrelasjon være positiv for læring og mestring. Forskning viser at like forventninger mellom lærerstudenter og praksisveiledere har stor betydning for lærerstudentens læring og utvikling. Sammenfallende forventninger mellom lærerstudenten og den samarbeidende læreren, kan ha sammenheng med lærerstudentens grad av opplevelse av læring og mestring. Ulike forventninger og uoverenstemmelser kan føre til store utfordringer i samarbeidet (Rajuan, Beijaard \& Verloop, 2010).

I programplanen for studiet legges det vekt på erfaringslæring gjennom studiet. Begrepet kan romme en dobbel betydning som kombinerer akkumulert kognitiv kunnskap med individets opplevelse (Dewey, 2008; Knudsen et al., 1999; Kolb, 1984). Gjennom refleksjon sammen med andre kan studentenes erfaringer fremstå som vesentlige, innholdsmessig og erkjennelsesmessig, å få stor betydning for dem og deres profesjonsutvikling gjennom sitt følelsesmessige engasjement. Når studenten ikke erfarer samarbeid på arbeidsplassen under sitt mastergradsarbeid slik som det fremgår av resultatene, er det ikke bare studenten som taper på dette, men også de som kunne ha samarbeidet med studenten. Arbeidsplassene tar ikke i bruk den ressursen som ligger i et kollegialt utviklingsarbeid. Dette gjenspeiler ikke den profesjonspraksis som Raaen (2010) hevder vil bidra til «å gjøre hverandre gode», gjennom å bidra i hverandres profesjonelle utvikling. Det støtter heller tanken om en kultur slik Engstrøm hevder, hvor læreren fremstår som en individuell tenker og ikke som en person som tenker og handler i samarbeid med andre (Engeström, 1994). En slik praksis vil heller ikke bidra til å nå nasjonale mål for skolene som virksomheter, for som det står i stortingsmeldingene; hvis skolene ikke mobiliserer de ansattes samlede kompetanse og stiller 
krav til faglig samarbeid i et kollegialt fellesskap, vil ikke ulik fagkompetanse og spesialisering hos lærerne fremstå som en styrke. Gode lærere er aktive bidragsytere i et profesjonelt faglig fellesskap som utvikler skolen som en lærende organisasjon (Meld. St. 20, 2012-2013, s. 158).

\section{Studentenes erfaringer av mastergradens betydning for kompetanseutvikling}

Spørsmål 5. "I hvilken grad erfarte du at din mastergrad fikk betydning for din arbeidsplass?"

Tabell 7

Viser grad av mastergradens betydning for studentens egen arbeidsplass

\begin{tabular}{|l|c|c|c|c|c|c|c|}
\hline & $\begin{array}{l}\mathbf{1} \\
\text { ikke }\end{array}$ & $\mathbf{2}$ & $\mathbf{3}$ & $\mathbf{4}$ & $\mathbf{5}$ & $\begin{array}{l}\mathbf{6} \\
\text { meget } \\
\text { stor }\end{array}$ & $\mathbf{N}$ \\
\hline $\begin{array}{l}\text { jeg du informerte selv } \\
\text { om arbeidet }\end{array}$ & $2,2 \%$ & $10,9 \%$ & $17,4 \%$ & $17,4 \%$ & $34,8 \%$ & $17,4 \%$ & 46 \\
\hline $\begin{array}{l}\text { arbeidet ble gjort kjent } \\
\text { gjennom møter på min } \\
\text { arbeidsplass }\end{array}$ & $28,3 \%$ & $13,0 \%$ & $23,9 \%$ & $6,5 \%$ & $21,7 \%$ & $6,5 \%$ & 46 \\
\hline $\begin{array}{l}\text { arbeidet ble diskutert i } \\
\text { faglige møter på min } \\
\text { arbeidsplass }\end{array}$ & $39,1 \%$ & $13,0 \%$ & $15,2 \%$ & $15,2 \%$ & $10,9 \%$ & $6,5 \%$ & 46 \\
\hline $\begin{array}{l}\text { arbeidet ble gjort kjent } \\
\text { på arbeidsplassens } \\
\text { hjemmeside }\end{array}$ & $80,4 \%$ & $10,9 \%$ & $4,3 \%$ & $4,3 \%$ & $\mathbf{0 , 0} \%$ & $\mathbf{0 , 0} \%$ & 46 \\
\hline $\begin{array}{l}\text { arbeidet har blitt } \\
\text { videreutviklet }\end{array}$ & $41,3 \%$ & $8,7 \%$ & $19,6 \%$ & $8,7 \%$ & $10,9 \%$ & $10,9 \%$ & 46 \\
\hline
\end{tabular}

Tabell 7 viser at studentene i liten grad har følt at deres mastergrad har hatt betydning for arbeidsplassen. Ved å slå sammen verdien 1 og 2, viser resultatene at $50 \%$ av studentene ikke eller i svært liten grad, har erfart at deres arbeid har blitt videreutviklet og benyttet på egen arbeidsplass. Over $90 \%$ har ikke erfart at deres arbeid har blitt formidlet på arbeidsplassens hjemmesider. I den grad studentenes arbeid har blitt formidlet til kolleger har det skjedd ved at studentene selv har informert. 39\% har ikke erfart at deres arbeid har blitt diskutert i faglige sammenhenger på arbeidsplassen. 
Spørsmål 6. "I hvilken grad erfarer du at masteroppgaven din har hatt betydning utenfor egen arbeidsplass ved at den ...?"

Tabell 8

Viser grad av mastergradens betydning utenfor egen arbeidsplass

\begin{tabular}{|c|c|c|c|c|c|c|c|}
\hline & $\begin{array}{l}1 \\
\text { ikke }\end{array}$ & 2 & 3 & 4 & 5 & $\begin{array}{l}6 \\
\text { meget } \\
\text { stor }\end{array}$ & $\mathbf{N}$ \\
\hline brukes på flere skoler & $41,3 \%$ & $23,9 \%$ & $15,2 \%$ & $13,0 \%$ & $6,5 \%$ & $0,0 \%$ & 46 \\
\hline $\begin{array}{l}\text { har bidratt til forbedring av } \\
\text { undervisning innen yrkesfag }\end{array}$ & $32,6 \%$ & $17,4 \%$ & $21,7 \%$ & $17,4 \%$ & $6,5 \%$ & $4,3 \%$ & 46 \\
\hline $\begin{array}{l}\text { har bidratt til } \\
\text { læreplanendring }\end{array}$ & $58,7 \%$ & $10,9 \%$ & $17,4 \%$ & $6,5 \%$ & $6,5 \%$ & $0,0 \%$ & 46 \\
\hline $\begin{array}{l}\text { har bidratt til nye } \\
\text { vurderingsformer innen fag } \\
\text { og yrkesopplæring }\end{array}$ & $43,5 \%$ & $21,7 \%$ & $19,6 \%$ & $6,5 \%$ & $4,3 \%$ & $4,3 \%$ & 46 \\
\hline $\begin{array}{l}\text { har bidratt til bedre } \\
\text { samarbeid mellom skole og } \\
\text { arbeidsliv }\end{array}$ & $26,1 \%$ & $23,9 \%$ & $13,0 \%$ & $17,4 \%$ & $13,0 \%$ & $6,5 \%$ & 46 \\
\hline
\end{tabular}

Tabell 8 viser at resultatene fra mastergradsoppgaven har hatt svært liten betydning også utenfor egen arbeidsplass. Ved å slå sammen verdiene 1,2 og 4,5,6, ser vi at enkelte studenters arbeid kan ha fått betydning i en viss grad for samarbeidet mellom skole og arbeidsliv. Nær $37 \%$ mener det. Resultatene viser også at $50 \%$ av studentene mener at deres masteroppgave i liten grad har hatt betydning for samarbeidet mellom skole og arbeidsliv. 58,7\% og 43,5\% har erfart at masteroppgaven ikke har ført til endringer av læreplaner eller vurderingsformer.

Spørsmål 7. "I hvilken grad erfarte du at den kompetansen du utviklet gjennom masterstudiet ble brukt ved at den...?" 
Viser graden av erfart bruk, av egen kompetanse utviklet under studiet

\begin{tabular}{|l|c|c|c|c|c|c|c|}
\hline & $\begin{array}{l}\mathbf{1} \\
\text { ikke }\end{array}$ & $\mathbf{2}$ & $\mathbf{3}$ & $\mathbf{4}$ & $\mathbf{5}$ & $\begin{array}{l}\mathbf{6} \\
\text { meget } \\
\text { stor }\end{array}$ & $\mathbf{N}$ \\
\hline $\begin{array}{l}\text { ble anvendt på din } \\
\text { arbeidsplass }\end{array}$ & $19,6 \%$ & $15,2 \%$ & $17,4 \%$ & $15,2 \%$ & $13,0 \%$ & $19,6 \%$ & 46 \\
\hline $\begin{array}{l}\text { påvirket ditt faglige } \\
\text { samarbeid med kolleger }\end{array}$ & $6,5 \%$ & $4,3 \%$ & $26,1 \%$ & $15,2 \%$ & $23,9 \%$ & $23,9 \%$ & 46 \\
\hline $\begin{array}{l}\text { påvirket din evne til å } \\
\text { forstå problemstillinger i } \\
\text { samfunnet generelt }\end{array}$ & $2,2 \%$ & $0,0 \%$ & $6,5 \%$ & $21,7 \%$ & $\mathbf{3 0 , 4 \%}$ & $\mathbf{3 9 , 1 \%}$ & 46 \\
\hline $\begin{array}{l}\text { påvirket din evne til å } \\
\text { skape samarbeid mellom } \\
\text { utdanning og arbeid }\end{array}$ & $2,2 \%$ & $0,0 \%$ & $4,3 \%$ & $19,6 \%$ & $\mathbf{3 2 , 6 \%}$ & $\mathbf{4 1 , 3 \%}$ & 46 \\
\hline $\begin{array}{l}\text { påvirket din evne til å } \\
\text { skape nettverk }\end{array}$ & $4,3 \%$ & $6,5 \%$ & $15,2 \%$ & $13,0 \%$ & $\mathbf{3 0 , 4 \%}$ & $\mathbf{3 0 , 4 \%}$ & 46 \\
\hline
\end{tabular}

Tabell 9 viser i hvilken grad studentene har erfart, at deres kompetanse utviklet gjennom masteroppgaven har blitt anvendt på egen arbeidsplass. Vi ser en tendens til at hele verdiskalaen er brukt på de to første variablene, og at det er nærmest like mange som erfarer at deres kompetanse blir brukt, som at den ikke blir brukt. På de variablene som ikke omhandler forhold på egen arbeidsplass, er resultatene bedre. Resultatene viser at studentene erfarer at deres studium har gitt dem økt kompetanse innen faglig arbeid, som evne til å skape nettverk, skape samarbeid mellom utdanning og arbeid og generell forståelse av samfunnsmessige problemstillinger. Nærmere $70 \%$ erfarer dette i stor grad, når vi ser på verdiene 5 og 6 under ett.

Jeg vil si at resultatene viser at hele praksisfeltet både skolene og bedriftene, får lite nytte av masteroppgavene i yrkespedagogikk. Det betyr at studentene ikke bidrar gjennom sin masteroppgave til å utvikle fag - og yrkesopplæringen. Masteroppgaven og studentenes kompetanse etter studiet kunne åpnet opp for nye arbeidsmuligheter for studentene.

Eksempelvis vil dette kunne være arbeid med skoleledelse, undervisning ved yrkesfaglærerutdanning, arbeid med ledelse og utvikling av fagopplæring i offentlig sektor, og i arbeidsgiver- og arbeidstakerorganisasjoner. I slike stillinger vil studentenes kompetanse kunne bidra til videre utvikling av det yrkespedagogiske og -didaktiske fagfeltet. Viktige faktorer for at denne påvirkningen skal finne sted, er at masterstudentenes arbeid gjøres kjent på egen skole og til praksisfeltet. Studentenes masterforskning bør løftes inn i det åpne rom i større grad enn i dag. For å lykkes med dette vil det være av stor betydning at studenten samarbeider under masteroppgaven med kolleger og arbeidsgiver på egen arbeidsplass eller 
eksternt. Det er viktig for relevans og kunnskapsutvikling i en eksemplarisk læringskontekst (Negt et al., 1997), at samarbeid med andre fremmes gjennom studiet.

Studentenes masteroppgaver gjennomføres i stor grad som utviklingsarbeid på egen arbeidsplass, som oftest er en videregående yrkesfaglig skole. Det at studentene erfarer egen kompetanseutvikling så markant, kan være et resultat av individuelt arbeid. Dette kan ha sammenheng med at de i så stor grad er alene med sine oppdagelser under arbeidet, som medfører betydelig grad av refleksjon og endring underveis. Å være i en situasjon hvor det prøves ut nye handlinger kan være utfordrende i seg selv, om man i tillegg, slik som studentene her, også har ansvar for elevers læring og progresjon, tenker jeg det bidrar til større grad av refleksjon og læring. Studentenes erfaringer blir her vesentlige, innholdsmessig og erkjennelsesmessig. Jeg vil si at dette er et vesentlig psykodynamisk element, da dette på flere måter berører og blir følelsesmessig engasjerende. Som studenter, der deres mastergradsarbeid er tett knyttet opp til deres daglige virksomhet, utgjør et vesentlig sosialt og samfunnsmessig element (Illeris, 2012; Knudsen et al., 1999). Negts begrep om «eksemplarisk læring» (Weber et al., 1997) er et særlig meningsfylt utgangspunkt i yrkespedagogikken der et av fundamentene i studiet er gjennomføring av utviklingsforskning. Det er da svært synd at erfaringsdeling og samarbeid er så lite fremtredende.

Det at studenten ikke i særlig grad får «honnør» for sitt arbeid på arbeidsplassen, betyr ikke at studenten har lite utbytte av studiet i forhold til egen kompetanse. Det betyr kun at sjansen for at nyttig kompetanse og erfaringer ikke blir delt og adoptert av andre på arbeidsplassen. For arbeidsplassen som en lærende organisasjon, er dette et tap og det reduserer muligheten til generell skoleutvikling. To viktige faktorer for studentenes kompetanseutvikling er mentoring/veiledning og jobbtilfredshet. Samarbeid og veiledning av kolleger og ledelse vil kunne $\varnothing$ ke kompetanseutviklingen og styrke effektiviteten av laring på arbeidsplassen. En tilpasset mentorrelasjon mellom studenter og ledere kan lindre negative psykologiske erfaringer (f. eks angst) og fremme faglig og personlig vekst (Rajuan et al., 2010). Studiet blir med andre ord et bidrag til individuell kompetanseutvikling og kunne i den sammenhengen godt vært gjennomført andre steder enn på studentens arbeidsplass. Det kan være at studentene ved å legge sitt utviklings- og forskningsarbeid ut i praksisfeltet, på bedrifter eller i arbeidslivsorganisasjoner, vil kunne erfare større interesse for masteroppgavens innhold og resultater. Ved en slik erfaring vil de få den mestringsfølelsen som gir deres arbeid en større mening. 


\section{Reliabilitetsanalyse}

For reliabilitetsanalyse med hensyn til indre konsistens målt med Cronbachs alfa, for skalaen som omfatter hovedspørsmål 5 med 4 underspørsmål, hovedspørsmål 6 med 4 underspørsmål, hovedspørsmål 7 med 7 underspørsmål og hovedspørsmål 8 med 4 underspørsmål, viste den statistiske analysen at Cronbachs alfa var henholdsvis 0.73, 0.74, 0.86, 0.92. Cronbachs alfa på 0.7 akseptabel (Pallant, 2010).

\section{Regresjonsanalyse}

Ved å gjennomføre en regresjonsanalyse ville jeg teste om variablene påvirker hverandre. Jeg valgte å teste om de avhengige variablene «sumskåre Erfart samarbeid med arbeidsgiver» og «sumskåre Erfart samarbeid med kolleger», påvirkes av de uavhengige variablene. Jeg ønsket derfor å få analysert om det er en signifikant sammenheng med disse variablene og de uavhengige variablene alder, arbeidssted, «sumskåre initiativ til samarbeid med kollegaer» og «sumskåre initiativ til samarbeid med arbeidsgiver. For å få belyst dette valgte jeg å gjøre en linear regresjonsanalyse. Sumskåre ble beregnet på hovedspørsmålene 5, 6, 7 og 8, med underspørsmål.

\begin{tabular}{|l|l|c|c|c|}
\hline \multicolumn{3}{|l|}{$\begin{array}{l}\text { Tabell } 10 \\
\text { Tabell for den }\end{array}$ avhengige variabelen erfart samarbeid med arbeidsgiver } \\
\hline \multirow{2}{*}{ Variabel } & Beta & sig & $\begin{array}{l}\text { Adjusted R } \\
\text { Square }\end{array}$ \\
\hline \multirow{2}{*}{ Avhengig variabel: Erfart samarbeid med arbeidsgiver } & & & \\
\hline \multirow{4}{*}{$\begin{array}{l}\text { Uavhengige } \\
\text { variabler }\end{array}$} & Grad av eget initiativ til samarbeid med arbeidsgiver & .478 & .002 & \\
\cline { 2 - 5 } & Hva var din alder ved avsluttet masteroppgave? & -.056 & .688 & \multirow{2}{*}{.158} \\
\cline { 2 - 5 } & Grad av eget initiativ til samarbeid med kolleger & .028 & .844 & \\
\cline { 2 - 5 } Avhengig variabel: & Erfart samarbeid med kolleger & .087 & .538 & \\
\hline \multirow{4}{*}{$\begin{array}{l}\text { Uavhengige } \\
\text { variabler }\end{array}$} & Grad av eget initiativ til samarbeid med arbeidsgiver & .020 & .889 & \multirow{2}{*}{.139} \\
\cline { 2 - 5 } & Hva var din alder ved avsluttet masteroppgave? & .030 & .833 & \\
\cline { 2 - 5 } & Grad av eget initiativ til samarbeid med kolleger & .444 & .003 & \\
\cline { 2 - 4 } & $\begin{array}{l}\text { Hvor var du ansatt da du gjennomførte ditt } \\
\text { masterstudium? }\end{array}$ & .118 & .413 & \\
\hline
\end{tabular}

Tallene i tabell 10 viser at det er en sammenheng mellom den uavhengige variabelen grad av initiativ til samarbeid med arbeidsgiver og den avhengige variabelen erfart samarbeid med 
arbeidsgiver. En signifikans på .002 kan aksepteres ut i fra at lavest mulig tall viser grad av troverdighet. Videre ser vi at de andre uavhengige variablene har verdi større enn $0.5 \mathrm{og}$ har derfor ingen betydning eller svært liten betydning. Det bekreftes med Beta på .478 for variabelen «initiativ til samarbeid arbeidsgiver» Beta viser jo høyere tall, jo sterkere sammenheng. Beta går fra -1 til +1. Vi kan derfor si at det er en sammenheng, noe som betyr at $\varnothing \mathrm{kt}$ initiativ til samarbeid vil gi økt erfart samarbeid. Den avhengige variabelen Erfart samarbeid med kolleger, viser noe av det samme. Sig .003 og Beta på .444, viser også at det er en sammenheng mellom økt initiativ og erfart samarbeid. Det kommer klart frem at de andre uavhengige variablene alder og arbeidstilhørighet har liten betydning. Ved å fjerne dem $\varnothing$ ker likevel ikke Adjusted R Square nevneverdig. Adjusted R Square på .158 og .139, viser at kun 16 og 14 prosent av de endringene som er påvist, skjer på bakgrunn av de uavhengige variablene initiativ samarbeid kollega og initiativ samarbeid arbeidsgiver. Det er svært lite og det vil klart være andre faktorer enn dem som er tatt med her som har betydning og kan forklare forholdet mellom initiativ og erfart samarbeid.

\section{Konklusjon}

Studien viser at det er en statistisk sammenheng mellom eget initiativ og samarbeid, men testene viser at dette kun er i en svært liten grad. Det er andre faktorer som spiller inn og disse er ikke tatt inn som variabler i undersøkelsen. Det er ikke gitt at kolleger og arbeidsgiver skal bli interessert selv om studenten tar initiativ til samarbeid. Vi har i en organisasjon også i skolen, ulike roller, kunnskapssyn, læringssyn, kort sagt ulike interesser. Og det er derfor mye som avhenger av skolens kultur for profesjonsutvikling og samarbeidslæring. Hvem tjener på dette og hvem kan tape? Det er derfor ikke innlysende at egen innsats vil gi økt samarbeid.

Når vi snakker om samarbeid, er det en viktig faktor at det er av interesse for alle parter som deltar. Mye av det samarbeidet som studentene har tatt initiativ til, er knyttet til rammer og gjennomføring av arbeidet, ikke faglig utbytte for studenten og arbeidsplassen. Et reelt samarbeid burde også omfattet en diskusjon om hvilken nytte både studenten og arbeidsplassen kan ha av masteroppgaven. Det vil derfor være viktig at kommende studenter oppfordres ytterligere til å diskutere tema for sitt arbeid med skolens ledelse og får forankret forsknings- og utviklingsarbeidet i en felles strategi. Dette vil kunne bidra til felles mål for arbeidet og klarere muligheter for samarbeid også med kolleger. Det vil kunne styrke studentens motivasjon gjennom studiet at flere enn en selv er interessert i resultatene. 
Studentene bør også formidle sine resultater til hele organisasjonen, noe som kan bidra til en bedre kultur for læring blant ansatte.

I videre forskning på feltet, vil det være interessant å utforske samarbeid utenfor studentenes egne arbeidsplasser. Denne artikkelen har vist at studentene ikke møter stor interesse for samarbeid i egen organisasjon. Et samarbeid med arbeidslivet utenfor egen arbeidsplass vil kanskje kunne sette studentens arbeid inn i et større samfunnsmessigperspektiv og gi gode muligheter til formidling av masteroppgavenes forskningsresultater. Ny kunnskap basert på erfaringer utviklet i samarbeid mellom høgskolen og arbeidslivet, vil kunne gi økt forskningsbasert kunnskap med høy grad av relevans for fag- og yrkesopplæring i samfunnet. 


\section{Referanser}

Bakke, K. R. \& Tønnesen, E. S. (2007). Lave \& Wenger og Dreyfus \& Dreyfus: laering $i$ et sosiokulturelt perspektiv (Hovedoppgave): Universitetet i Oslo, Oslo.

Berthelsen, J., Illeris, K. \& Poulsen, S. C. (1988). Innføring i prosjektarbeid. [Oslo]: Fag og kultur.

Dewey, J. (2005). Demokrati og uddannelse. Århus: Forlaget Klim.

Dewey, J. (2008). Erfaring og opdragelse. København: Reitzel.

Dysthe, O. (2001). Dialog, samspel og loering. Oslo: Abstrakt forl.

Engeström, Y. (1994). Training for change: new approach to instruction and learning in working life. Geneva: International Labour Office.

Freire, P. (1999). De undertryktes pedagogikk (S. Lie, Overs., 2. utg.). Oslo: Ad notam Gyldendal.

Gadamer, H.-G. (1989). Truth and method (J. Weinsheimer, \& D. G. Marshall, Overs., 2. utg.). London: Sheed \& Ward.

Gilje, N. (1987). Hermeneutikk $i$ vitenskapsteoretisk perspektiv (Skriftserien nr. 6). Bergen: Universitetet i Bergen.

Grendstad, N. M. \& Sandven, G. J. (1986). A lcere er å oppdage: prinsipper og praktiske arbeidsmåter i konfluent pedagogikk. Oslo: Didakta.

Grønmo, S. (2004). Samfunnsvitenskapelige metoder. Bergen: Fagbokforl.

Hiim, H. (2013). Praksisbasert yrkesutdanning: hvordan utvikle relevant yrkesutdanning for elever og arbeidsliv? Oslo: Gyldendal akademisk.

Hiim, H. \& Hippe, E. (2001). A utdanne profesjonelle yrkesutøvere. Oslo: Gyldendal akademisk.

Hiim, H. \& Hippe, E. (2013). A utdanne profesjonelle yrkesutøvere: yrkesdidaktikk og yrkeskunnskap. Oslo: Gyldendal akademisk.

Hovdehaugen, E., Frøseth, M. W. \& Aamodt, P. O. (2010). Fullføring og frafall på hovedfag og mastergrad: En sammenligning av kullene som begynte i 1999 og 2003 (NIFU STEP-rapport nr. 5/2010). Oslo: NIFU.

Høgskolen i Oslo og Akershus. (2013). Programplan for master i yrkespedagogikk. Hentet fra http://www.hioa.no/Mediabiblioteket/node 52/node 869/LU/node 1004/Programplan -master-i-yrkespedagogikk-kull-2013-2017

Høie, M. (2008). Studentenes erfaringer med hovedfagsstudiet i yrkespedagogikk 1998-2007 (Småskrift nr. 2/2008). Lillestrøm: Høgskolen i Akershus. 
Høie, M. (2010). Mastergrad i yrkespedagogikk 2003-2009: En oppfølgingsundersøkelse (Småskrift nr. 6/2010). Lillestrøm: Høgskolen i Akershus.

Illeris, K. (1981). Modkvalificeringens paedagogik: problemorientering, deltagerstyring og eksemplarisk indlcering. København: Unge pædagoger.

Illeris, K. (2012). Loering (Y. Nordgård, Overs.). Oslo: Gyldendal akademisk.

Innbjør, H. \& Kleiveland, J. (2007). Operativt lederskap. Bergen: Fagbokforlaget

Johannessen, A., Christoffersen, L. \& Tufte, P. A. (2010). Introduksjon til samfunnsvitenskapelig metode. Oslo: Abstrakt.

Kjørup, S. (2008). Menneskevidenskaberne: del 2. Humanistiske forskningstraditioner (2. utg.). Frederiksberg: Roskilde Universitetsforlag.

Knudsen, S. V., Illeris, K., Kristensen, H. J., Foss Hansen, K., Borgnakke, K., Knudsen, S. V., . . . Kupferberg, F. (1999). Projektarbejdets fortid og fremtid. København: Danmarks Lærerhøjskole.

Kolb, D. A. (1984). Experiential learning: experience as the source of learning and development. Englewood Cliffs, N.J.: Prentice-Hall.

Kvale, S. \& Brinkmann, S. (2009). Interviews. Learning the craft of qualitative research interviewing. Los Angeles: SAGE, 2nd ed

Meld. St. 20. (2012-2013). På rett vei: Kvalitet og mangfold i fellesskolen. [Oslo]: Kunnskapsdepartementet.

Meld. St. nr 13. (2011-2012). Utdanning for velferd. Oslo: Kunnskapsdepartementet.

Negt, O., Weber, K., Steen Nielsen, B. \& Salling Olesen, H. (1997). Modet til fremtiden: inspirationen fra Oskar Negt. [Fredriksberg]: Roskilde universitetsforl.

Nielsen, L. D., Nielsen, K. A., Munk-Madsen, E. A. \& Hartmann-Petersen, K. (2010). Fleksibilitet, flygtighed og frirum: en kritisk diagnose af det senmoderne arbejdsliv. Fredriksberg: Roskilde Universitetsforlag.

Pallant, J. (2010). SPSS survival manual: a step by step guide to data analysis using SPSS. Maidenhead: McGraw-Hill.

Patton, M. Q. (2002). Qualitative research \& evaluation methods. Thousand Oaks, Calif.: Sage Publications.

Raaen, F. D. (2010). Læring i yrket: i møtet mellom erfarne og nyutdannede. I T. L. Hoel, G. Engvik, \& B. Hanssen (Red.), Ny som loerer (s. 235-249). Trondheim: Tapir akademisk forl.

Rajuan, M., Beijaard, D. \& Verloop, N. (2010). The match and mismatch between expectations of student teachers and cooperating teachers: exploring different 
opportunities for learning to teach in the mentor relationship. Research Papers in Education, 25(2), 201-223. doi:10.1080/02671520802578402

Schwencke, E. \& Larsen, A. K. (2011). Spenningsfeltet mellom "nytte" for bedriften og "frirom" for studenten: et samarbeidsprosjekt mellom skole og arbeidsliv for gjensidig påvirkning og ønske om forandring. Nordic journal of vocational education and training, 1(1), 1-14.

St. Meld. nr 44. (2008-2009). Utdanningslinja. [Oslo]: Kunnskapsdepartementet.

Utdanningsdirektoratet. (2009). OECDs internasjonale studie av undervisning og laering (TALIS). Hentet fra http://www.udir.no/Upload/Rapporter/TALIS2008/5/TALIS08_sammendrag.pdf?epslanguage $=$ no

Wan, C.-S., Yang, J.-T., Cheng, S.-Y. \& Su, C. (2013). A longitudinal study on internship effectiveness in vocational higher education. Educational Review, 65(1), 36-55. doi:10.1080/00131911.2011.634969

Weber, K., Olesen, H. S. \& Nielsen, B. S. (1997). Modet til fremtiden: inspirationen fra Oskar Negt. Frederiksberg: Roskilde Universitetsforlag.

Wenger, E. (2009). A social theory of learning. I K. Illeris (Red.), Contemporary theories of learning : Learning theorists, in their own words (s. 209-218). London: Routledge. 